\title{
Developing Critical Success Factors (CSFs) for Effective Construction Management in Malaysia Industry
}

\author{
Ayob. Norizam ${ }^{1} \&$ M. A. Malek ${ }^{1}$ \\ ${ }^{1}$ Civil Engineering Dept., University Tenaga Nasional, Kajang, Malaysia \\ Correspondence: Ayob. Norizam, Civil Engineering Dept., University Tenaga Nasional, Kajang, Malaysia. Tel: \\ 60-1226-1847. E-mail: norizamayob@yahoo.com
}

Received: March 24, 2013 Accepted: April 17, 2013 Online Published: June 29, 2013

doi:10.5539/ass.v9n9p211 URL: http://dx.doi.org/10.5539/ass.v9n9p211

\begin{abstract}
Construction management $(\mathrm{CM})$ can be considered as the central concern in conducting of construction projects. In order to deliver high-quality product to both purchaser and buyer, there is a need to assess the efficiency of the company behind the product. Despite numerous journal papers explaining critical success factors (CSFs) for construction projects, very few focus on determining the CSFs for construction management. The primary objective of this paper is to identify the principal CSFs for construction management through literature review and survey. From the review, seven main factors can be determined from all of the sub-factors discovered. Those factors were assembled into a questionnaire and distributed among construction industry practitioners, including property developers, consultants and contractors. An analysis of factors was then used to ascertain the dependent and independent variables necessary for developing an assessment system for evaluating construction management in construction industry firms. The exploratory research in this paper focuses on the link between CSFs and an effectiveness in construction management for construction industry practitioners in Malaysia.
\end{abstract}

Keywords: construction management, quality management, management, construction, critical success factor (CSF)

\section{Introduction}

Project performance is influenced by various factors, some of which contribute to the project's success more than others (Sanvido, 1992). Construction management (CM) needs to identify all the vital factors of their projects in order to produce high-quality product and satisfy the buyer. Stadelmann (2007) listed some of the factors that are considered by buyers, such as location, size, mortgage, living cost, school catchment area, public transport and others. With the increasing rate of property development, purchasers and buyers are more careful to make sure that property they purchase returns acceptable value for their money. As project values and contractor capabilities increase, the level of quality product should also increase.

As the basis of successful construction project completion, effective $\mathrm{CM}$ will not only benefit construction firms, but also the other involved parties. The effectiveness of $\mathrm{CM}$ will lead to increased product quality, improvement in workman efficiency, decreases in wastage and higher profits (Bubshait, 1999). Proper CM should apply not only to companies primarily engaged in new construction, but also heavy construction, additions, alterations, reconstruction, installation and maintenance and repairs (U.S. Census Bureau, 2002).

Through a literature review on critical success of construction projects, previous explanations are based on theoretical rather than empirical proof, and few academic studies have been conducted (Koushki, 2005). Those findings motivated the authors to develop the present research by specifically aiming to identify the CSFs necessary for effective CM, and would later be used in developing a questionnaire for field study.

\section{Literature Review}

\subsection{Critical Success Factors (CSFs) for Construction Project}

By 1982, CSFs had been defined as a tool to identify executive information needs (Rockart 1982). They had been used in management information systems (MIS) to examine their existing methodologies, and from time to time, CSFs had been widely used by other industries, including the construction industry. Generally, CSFs integrate with eight elements that are used as benchmarking parameters: structure of industry, competitive strategy, market conditions, political environment, organizational structure, technical applications, employee 
enhancements and process benchmarking (Rockart 1982; Sanvido 1982; Abraham 2004).

Today, there are increasing numbers of researchers who are intent on enhancing the use of CSFs for construction projects. Chan (2004) identified five primary CSFs from 44 identified factors, which are: (Yong Qiang Chen, 2012) project-related factors, project procedures, project management actions, human-related factors and external environment. Iyer and Jha (2005) established attributes that related to schedule and performance, listing 55 attributes that were subsequently grouped into six CSFs and seven critical failure success (CFF). Those factors are project managers' competence, supportive owners, top management monitoring, feedback, and coordination. Li (2005) identified 55 attributes and grouped them into five CSFs for public-private partnership (PPP) projects in the United Kingdom (UK). Those five categories were: effective procurement, project implementation ability, government guarantees, favorable economic conditions, and the available financial market. Abraham (2004) identified seven CSFs that influence the success of construction projects: competitive strategy, market analysis, political environment, economic environment, technical application, employee/organizational enhancement and process benchmarking. Saqib (2008) listed the top five CSFs affecting Pakistan's construction industry, developed from 77 identified factors: contractor-related factors, project management factors, procurement-related factors, design team-related factors and project management factors.

All factors identified from the literature survey have been tabulated in Table 1.

Table 1. Critical success factors (CSF) summarization refining from literature survey

\begin{tabular}{lllll}
\hline $\begin{array}{c}\text { (Chan A.P.C., } \\
\text { 2004) }\end{array}$ & \multicolumn{1}{c}{ (Iyer, 2005) } & \multicolumn{1}{c}{$(\mathbf{L i}$, 2005) } & \multicolumn{1}{c}{ (Abraham, 2004) } & \multicolumn{1}{c}{$\begin{array}{c}\text { (Muhammad } \\
\text { Saqib, 2008) }\end{array}$} \\
\hline $\begin{array}{l}\text { 1. project } \\
\text { related factors }\end{array}$ & 6. project & 12. effective & 17. competitive strategy & 24. contractor- \\
managers' & procurement & $\begin{array}{l}\text { 18. market analysis } \\
\text { related factors }\end{array}$ \\
procedures & competence & 13. project & 19. political environment & 25. project \\
3. project & 7. supportive & implement ability & 20. economic & management \\
management & owners & 14. government & environment & factors \\
actions & 9. monitoring & 15. favorable & 21. employee/organizatio & related factors \\
4. human & 10. feedbacks & economic & nal enhancement & 27. design-team \\
related factors & 11. coordination & conditions & 23. process & related factors \\
5. external & & 16. available & benchmarking & 28. Project \\
environment & & financial market & & management \\
& & & & factors. \\
\hline
\end{tabular}

\section{Research Methodology}

In developing parameters to be used in current research, researcher had integrated previous CSF obtained from literature survey and project management knowledge area listed in PMBOK.

In chapter two Project Management Book of Knowledge (PMBOK), they had identified nine management areas that can be used to benchmark the knowledge area of practitioners towards the successful of project: project integration, project scope, project time, project cost, project quality, project human resource, project communications, project risk and project procurement management. (PMI Standards Committee, 1996) Any repetitive variables had been eliminated. Factors listed by (PMI Standards Committee, 1996) in research questionnaire as be considered as dependent variables and literature survey factors as dependent variables. Any variable that has not fall or related with any (PMI Standards Committee, 1996) then listed as "external management factors". 
Table 2. Research questionnaire independent (IV) and dependent variable (DV)

\begin{tabular}{|c|c|}
\hline Independent Variables & Dependent variables \\
\hline \multirow[t]{2}{*}{ project integration management } & project related factors \\
\hline & project procedures \\
\hline \multirow[t]{2}{*}{ project scope management } & project implement ability \\
\hline & process benchmarking \\
\hline \multirow{2}{*}{ project time management } & monitoring \\
\hline & coordination \\
\hline project cost management & available financial market \\
\hline project quality management & monitoring \\
\hline \multirow{2}{*}{ project human resource management } & human related factors \\
\hline & employee/organizational enhancement \\
\hline \multirow{4}{*}{ project communications management } & feedbacks \\
\hline & coordination \\
\hline & available financial market \\
\hline & favorable economic conditions \\
\hline \multirow[t]{3}{*}{ project risk management } & market analysis \\
\hline & economic environment \\
\hline & political environment \\
\hline \multirow[t]{6}{*}{ project procurement management } & effective procurement \\
\hline & project management actions \\
\hline & external environment \\
\hline & project managers' competence \\
\hline & supportive owners \\
\hline & top management \\
\hline \multirow[t]{6}{*}{ Others management factors } & government guarantee \\
\hline & competitive strategy \\
\hline & technical application \\
\hline & contractor- related factors \\
\hline & design-team related factors \\
\hline & Project management factors \\
\hline
\end{tabular}

Base from Table 3: Research Questionnaire Structure there are some repetitive factors had fall into few categories. Those variables then being group with sub item obtained from (PMI Standards Committee, 1996) in order to determine the correlation between variables. The investigation on the factors contributes to the CSF of construction management presented in the final questionnaire comprising as 
Table 3. Research questionnaire structure

\begin{tabular}{|c|c|c|}
\hline Item & Section & Independent variables \\
\hline A: & Respondent background & $\begin{array}{l}\text { Type of organization } \\
\text { Contractor grade } \\
\text { Respondent Designation } \\
\text { Construction industry experiences } \\
\text { Gender }\end{array}$ \\
\hline B: & $\begin{array}{l}\text { Construction Integration } \\
\text { Management }\end{array}$ & $\begin{array}{l}\text { Construction Plan Development } \\
\text { Construction Plan Execution } \\
\text { Overall Change Control }\end{array}$ \\
\hline $\mathrm{C}:$ & Construction Scope Management & $\begin{array}{l}\text { Initiation } \\
\text { Scope Definition } \\
\text { Scope Planning } \\
\text { Scope Verification }\end{array}$ \\
\hline D: & Construction Time Management & $\begin{array}{l}\text { Activity Definition } \\
\text { Activity Sequencing } \\
\text { Activity Duration Estimating } \\
\text { Schedule Development } \\
\text { Schedule Control }\end{array}$ \\
\hline $\mathrm{E}:$ & Construction Cost Management & $\begin{array}{l}\text { Resource Planning } \\
\text { Cost Estimation } \\
\text { Cost Budgeting } \\
\text { Cost Control }\end{array}$ \\
\hline F: & Construction Quality Management & $\begin{array}{l}\text { Quality Planning } \\
\text { Quality Assurance } \\
\text { Quality Control }\end{array}$ \\
\hline G: & $\begin{array}{l}\text { Construction Human Resources } \\
\text { Management }\end{array}$ & $\begin{array}{l}\text { Organizational Planning } \\
\text { Organizational Planning } \\
\text { Organizational Planning } \\
\text { Staff Acquisition } \\
\text { Team Development }\end{array}$ \\
\hline $\mathrm{H}:$ & Construction Risk Management & $\begin{array}{l}\text { Risk Identification } \\
\text { Risk Quantification } \\
\text { Risk Response Development } \\
\text { Risk Response Control }\end{array}$ \\
\hline
\end{tabular}

\subsection{Population and Sampling Size}

The collection of data was held in Malaysia from October 2012 until middle of December 2012. Samples were randomly selected from the list of property developers, consultants and contractors. A total of one hundred (100) questionnaires were distributed to construction industries practitioners all over Malaysia. From that, total of 77 were replied and being used for data analysis. 
Table 4. Respond rate by type of organization

\begin{tabular}{lll}
\hline Type of Organization & Number of respondent(s) & Percentage contributed \\
\hline Government & 15 & $19.48 \%$ \\
Consultant & 17 & $22.08 \%$ \\
Property Developer & 22 & $28.57 \%$ \\
Contractor & 19 & $24.68 \%$ \\
Others & 4 & $5.19 \%$ \\
TOTAL & 77 & $100 \%$ \\
\hline
\end{tabular}

As shown in Table 4: Respond rate by type of, a total of seventy seven (77) questionnaires were collected from different group of practitioners. According to (A, 2007) reported that in construction industry, normal response rate is around 20-30 percent and with current respond rate it means that it can be acceptable. From total of one hundred (100), seventy seven (77) replied and contributed to $77 \%$ of responds rate. Out of that: Government Sector -15 respondents (19.48\%), Consultant Sector -17 respondents (22.08\%), Property Developer Sector 22 respondents $(28.57 \%)$, Contractor Sector -19 respondents $(24.68 \%)$ and Other Sector -4 respondents (5.19\%).

\section{Results and Analysis}

Table 5 to 11 present the result of the analysis of the factors that are identified as critical for construction management in construction project in Malaysia. Twenty-six (26) factors had been grouped into seven (7) categories. Each grouped of factors were ranked according to their means value.

\subsection{Construction Integration Management}

Table 5 indicated results with regards to construction integration management. Three factors were identified in this category. Construction Plan Development is among the top of all factors having a mean score of 4.3. While Construction Plan Execution and Overall Change Control scored a mean score of 4.21 and 4.16.

Table 5. Ranking of construction integration management contributing to success of construction management

\begin{tabular}{lcccc}
\hline Construction Integration Management & N & Mean & Std. Deviation & Ranking \\
\hline Construction Plan Development & 77 & 4.30 & .515 & 1 \\
Construction Plan Execution & 77 & 4.21 & .675 & 2 \\
Overall Change Control & 77 & 4.16 & .796 & 3 \\
\hline
\end{tabular}

\subsection{Construction Scope Management}

From Table 6, there are four factors that identified under construction scope management. From all factors, scope definition is identified as the highest score of mean with 4.3. It then followed by scope verification, planning and initiating. They carried the mean score with 4.21, 4.18 and 4.10.

Table 6. Ranking of construction scope management contributing to success of construction scope management

\begin{tabular}{lcrrr}
\hline Construction Scope Management & N & Mean & Std. Deviation & Ranking \\
\hline Initiation & 77 & 4.10 & .661 & 4 \\
Scope Planning & 77 & 4.18 & .683 & 3 \\
Scope Verification & 77 & 4.21 & .614 & 2 \\
Scope Definition & 77 & 4.30 & .650 & 1 \\
\hline
\end{tabular}

\subsection{Construction Time Management}

Table 7 indicates ranking for construction scope management. Five factors fall under this category. Activity Definition ranked as the highest means score with 4.22. Then it followed by Activity Sequencing with 4.14. 
Activity Duration, Schedule Development and Schedule control ranked at number 4, 5 and 6 with mean score of $4.01,3.75$ and 3.94 .

Table 7. Ranking of construction time management contributing to success of construction time management

\begin{tabular}{lrrrrr}
\hline Construction Time Management & N & & Mean & \multicolumn{1}{c}{ Std. Deviation } & Ranking \\
\hline Activity Definition & 77 & 4.22 & .661 & 1 \\
Activity Sequencing & 77 & 4.14 & .773 & 2 \\
Activity Duration & 77 & 4.01 & .803 & 3 \\
Schedule Development & 77 & 3.75 & .945 & 4 \\
Schedule Control & 77 & 3.94 & 1.043 & 5 \\
\hline
\end{tabular}

\subsection{Construction Cost Management}

Table 8 presents the results of the analysis for construction scope management. There are four factors being analyzed under this category. Cost control was on top of other factors with mean score of 4.40. Cost budgeting at number 3 with mean score of 4.21 followed by resource planning and cost estimation with mean score of 4.06 and 3.92 .

Table 8. Ranking of construction cost management contributing to success of construction cost management

\begin{tabular}{|c|c|c|c|c|}
\hline Construction Cost Management & $\mathbf{N}$ & Mean & Std. Deviation & Ranking \\
\hline Resource Planning & 77 & 4.06 & .984 & 3 \\
\hline Cost Estimation & 77 & 3.92 & .791 & 4 \\
\hline Cost Control & 77 & 4.40 & .654 & 1 \\
\hline Cost Budgeting & 77 & 4.21 & .570 & 2 \\
\hline
\end{tabular}

\subsection{Construction Quality Management}

Table 9 indicates factors contributed for construction scope management. Highest mean score is quality assurance with 4.44. Both quality planning and quality control ranked as number 2 and 3 with mean score of 4.43 and 4.31 .

Table 9. Ranking of construction scope management contributing to success of construction quality management

\begin{tabular}{lrrrr}
\hline Construction Quality Management & N & Mean & Std. Deviation & Ranking \\
\hline Quality Planning & 77 & 4.43 & .637 & 2 \\
Quality Control & 77 & 4.31 & .595 & 3 \\
Quality Assurance & 77 & 4.44 & .550 & 1 \\
\hline
\end{tabular}

\subsection{Construction Human Resource Management}

From table 10, three factors being categorized under construction scope management with staff acquisition indicated as highest mean score that is 4.14 . Organizational planning and team development shared same mean score value with 3.90 .

Table 10. Ranking of construction scope management contributing to success of construction human resource management

\begin{tabular}{lrrrr}
\hline Construction Human Resource Management & N & Mean & Std. Deviation & Ranking \\
\hline Organizational Planning & 77 & 3.90 & $1 . .042$ & 2 \\
Staff Acquisition & 77 & 4.14 & 1.060 & 1 \\
Team Development. & 77 & 3.90 & 1.119 & 2 \\
\hline
\end{tabular}




\subsection{Construction Risk Management}

Based on table 11, construction scope management listed 4 factors that contributing to it success. Risk identification ranked as top of the factors list with 4.53.Others factor that listed under risk management categories are Risk Quantification, Risk Response Development and Risk Response Control with mean score of 4.16, 4.32 and 4.13 .

Table 11. Ranking of construction scope management contributing to success of construction risk management

\begin{tabular}{lcrrrr}
\hline Construction Risk Management & N & & Mean & Std. Deviation & Ranking \\
\hline Risk Quantification & 77 & 4.16 & .581 & 3 \\
Risk Identification. & 77 & 4.53 & .754 & 1 \\
Risk Response Development & 77 & 4.32 & .768 & 2 \\
Risk Response Control & 77 & 4.13 & .848 & 4 \\
\hline
\end{tabular}

Based on the findings, out of twenty-six factors that being analyzed - Construction Scope Management, Construction Time Management and Construction Cost Management indicated that some of their factors evaluated with less than 4 points and it is under considerable significant impact. Those factors will be eliminated for developing of construction assessment management tools. Hence, the significance to the effectiveness of the tools will then being criticizes.

\section{Conclusion}

This paper investigates factors that contributed to the critical success factors for effective construction management in construction industry through a survey conducted in Malaysia. Through the survey, researcher identified some missing parameters that might be consolidated from perspective of construction industry practitioners. Practitioners suggested that some enhancement on the survey that included assessment on practitioners financial status, construction managers specific task and responsibilities and relationship between quality control and safety measures to be add on for measuring construction management effectiveness.

It is evidence that construction industry in Malaysia recognized and implemented effective construction management in their firms but only they have not realized the contribution towards the successful on construction project.

Further research can be carried out to search the relationship between effective construction management and effective construction quality control process in establishing the most fit procedure and system in order to assess their capabilities for delivering high quality construction products.

\section{Acknowledgements}

Author would like to thank those respondents that answering survey questionnaire and contributed idea in enhancing listed parameters.

\section{References}

A., A. (2007). Analysis of factors influencing project cost estimating practice. Construction Management and Economics, 192-206.

Abdulaziz, A., \& Bubshait, M. A. A. (1999). ISO 9000 Quality Standards in Construction. Management in Engineering, 41-46.

Abraham, G. L. (2004). Critical Success factors for the Construction Industry. Construction Research Congress (pp. 1-9). ASCE 2004.

Bureau, U. C. (2002). All other speacility trade contractors: 2002 Economic Census, Economics. US.

Chan, A. P. C., \& S., D. (2004). Factors Affecting the success of a construction project. Construction Engineering Management, 153-155. http://dx.doi.org/10.1061/(ASCE)0733-9364(2004)130:1(153)

Iyer, K. A. (2005). Factors effecti9ng cost performance: Evidence from Indian construction projects. International Journal Project Management, 283-295. http://dx.doi.org/10.1016/j.ijproman.2004.10.003

Koushki, P. A., \& A.-R., K. (2005). Delays and cost increases in construction of private residential projects in kuwait. Construction Management Economy, 285-294. http://dx.doi.org/10.1080/0144619042000326710 
L., S. (2007, October 2). Factors to consider before buying a property to live in. USA.

Li, B. A. (2005). Critical Success factors for PPP/PFI projects in the UK construction industry. Construction Management Economic, 459-471. http://dx.doi.org/10.1080/01446190500041537

Muhammad Saqib, R. U. (2008). Assessment of Critical Success Factors for Construction Projects in Pakistan. First International Conference on Construction in Developing Countries (pp. 392-404). Pakistan.

PMI Standards Committee, W. R. (1996). A Guide to the Project Management Book of Knowledge. Project Management Institute.

Rockart, J. (1982). The changing role of information system executive: A critical success factors perspective. Sloan management Review, 3-13.

Sanvido V, G. F. (1992). Critical Success Factors for construction projects. Construction Engineering Management, 94-111. http://dx.doi.org/10.1061/(ASCE)0733-9364(1992)118:1(94)

Yong Qiang Chen, Y. B. (2012). Interrelationships among Critical Success Factors of Construction Projects Based on the Structural Equation Model. Management in Engineering, 243-251.

\section{Copyrights}

Copyright for this article is retained by the author(s), with first publication rights granted to the journal.

This is an open-access article distributed under the terms and conditions of the Creative Commons Attribution license (http://creativecommons.org/licenses/by/3.0/). 